\title{
Water consumption peak demand factor: Effectiveness analysis with different approaches
}

\author{
Coeficiente de pico de consumo de água: Análise de eficácia \\ com diferentes abordagens
}

\author{
Kauan Polli de Oliveira' \\ Daniela Bonazzi Sodek" \\ Laura Maria Canno Ferreira Fais ${ }^{\prime \prime \prime}$ \\ José Gilberto Dalfré Filho ${ }^{\text {IV }}$ \\ André Luís Sotero Salustiano Martimv
}

\begin{abstract}
The design of the water distribution networks in a given region must guarantee 24-hour supply, meeting the times of greatest demand, defined as factors of peak consumption. Thus, it is important that water reaches users effectively, ensuring adequate quantity and quality for carrying out daily activities. The premise then is the average flow demanded by the population, and the fluctuations that may occur from this value, weighted from the dimensionless peak coefficients $K_{1}$ (coefficient of the day of greatest consumption) and $K_{2}$ (coefficient of the hour of greatest consumption). In this paper, these coefficients are calculated from both water consumption data and from the application of empirical equations. These values were compared with those suggested by the NBR 12218/2017 standard, which suggests $K_{1}=1.2$ and $K_{2}=1.5$ in the absence of water consumption data. However, some surveys that assessed water consumption in three regions based on water consumption data for three to four years indicated that the peak coefficients recommended by the standard may lead to undersizing of the supply network. In one of the cases assessed, the values of $K_{1}$ and $K_{2}$ respectively corresponded to 2.19 and 4.95. Results of two studies previously developed at the Faculty of Civil Engineering, Architecture and Urbanism of the State University of Campinas (FEC-UNICAMP) were used for the calculation based on water consumption data. These studies defined the peak water consumption coefficients for the same three regions examined by the present research: Parque Jambeiro and Parque Oziel, located in the city of Campinas (third most populous city in the State of São Paulo, with an estimated 1,204,703 inhabitants in 2019), and Jardim América II, located in the municipality of Várzea Paulista, in the interior of the State of São Paulo, based on data provided by the water provider. The analyses carried out considered that the peak water consumption factor $\mathrm{Cp}$ is given by the product of $\mathrm{K}_{1}$ and $\mathrm{K}_{2}$. Seven empirical equations, available in the specific literature and developed in different locations, were used. As the empirical equations were developed in different regions, the average of the results obtained through these equations was used in order to reduce the existing uncertainties, related, for example, to the socioeconomic profile and climate, parameters that vary according to the region of study. As a result, this research shows that in all the neighborhoods observed, the normative suggestion for the $\mathrm{Cp}$ value was below those obtained by applying the empirical equations in all the
\end{abstract}

\footnotetext{
'Universidade Estadual de Campinas, Campinas, SP. Brasil -. kauanpolli1998@gmail.com.

'Universidade Estadual de Campinas, Campinas, SP. Brasil - danibonazzi@hotmail.com.

'Universidade Estadual de Campinas, Campinas, SP. Brasil - laura@ft.unicamp.br.

'Universidade Estadual de Campinas, Campinas, SP. Brasil - dalfre@unicamp.br.

v IUniversidade Estadual de Campinas, Campinas, SP. Brasil - . sotero@fec.unicamp.br.
} 
years used to calculate the coefficient. So, there was no year in which the normative reference was sufficiently adequate to describe water consumption. Furthermore, the evaluation using water consumption data resulted in a peak coefficient equivalent to $240 \%$ of the normative suggestion ( 2.4 times higher) whereas the empirical equations suggest the adoption of a value corresponding to $200 \%$ of the indicated value by the standard (twice as high). It was also found that the computation of $\mathrm{Cp}$ through empirical equations resulted in values 1.55 times higher than those obtained from the water consumption data. As the calculation of the design flow depends directly on the peak consumption coefficient, the use of smaller values leads to lower design flow and, consequently, to undersized network diameters. As a direct consequence, there are greater head losses at times of higher flow. This situation should result in a lack of water in peak consumption days and times, so as not to serve the population continuously, which is a premise of the public supply system. Future research may focus on expanding the number of regions evaluated in the comparison between different ways to calculate the peak water consumption coefficients, and it is also possible to explore the evaluation of water consumption data to determine the $\mathrm{Cp}$ value and the subsequent correlation with local factors such as resident population, supplied area, typical climate, among other factors, adding value to the results already existing in the specific literature, and also expanding the knowledge related to the dimensioning of water distribution networks.

Keywords: Peak demand factor; Empirical equations; Water consumption.

\section{Resumo}

O dimensionamento das redes de distribuição de água em uma determinada região deve garantir o suprimento de água 24 horas por dia, antendendo os horários de maior demanda, definidos como fatores de pico de consumo. Desta forma é importante que a água chegue aos usuários de maneira eficaz, garantindo a quantidade e a qualidade adequadas para a realização das atividades necessárias. Tem-se então como premissa a vazão média demandada pela população, e as flutuações que podem ocorrer deste valor, ponderadas a partir dos coeficientes adimensionais de pico K1 (coeficiente do dia de maior consumo) e K2 (coeficiente da hora de maior consumo). Neste trabalho, estes coeficientes foram calculados através de dados de consumo hídrico e também através da aplicação de equações empíricas. Estes valores foram comparados com os valores sugeridos pela norma NBR 9649/1986, que indica o uso dos valores K1 =1,2 e K2 =1,5 na falta dos dados de consumo hídrico. Entretanto, algumas pesquisas que avaliaram o consumo hídrico de três regiões com base nos dados de consumo hídrico de três a quatro anos indicaram que os coeficientes de pico recomendados pela norma podem incorrer em subdimensionamento. Em um dos casos avaliados, os valores de K1 e K2 respectivamente corresponderam a 2,19 e 4,95. Resultados de dois estudos previamente desenvolvidos na Faculdade de Engenharia Civil, Arquitetura e Urbanismo da Universidade Estadual de Campinas (FEC-UNICAMP) foram utilizados para os cálculos baseados em dados de consumo hídrico. Estes estudos definiram os coeficientes de pico de consumo hídrico para as mesmas três regiões examinadas pela presente pesquisa: Parque Jambeiro e Parque Oziel, localizados no município de Campinas, e Jardim América II, situado no município de Várzea Paulista, interior do Estado de São Paulo, com base em dados fornecidos pelas concessionárias. As análises realizadas levaram em consideração que o coeficiente de pico de consumo hídrico $\mathrm{Cp}$ é dado pelo produto entre K1 e K2. Sete equações empíricas, disponíveis na literatura específica e desenvolvidas em diferentes localidades, foram utilizadas. Como as equações empíricas foram desenvolvidas em diferentes regiões, foi utilizada a média dos resultados obtidos através destas equações, a fim de diminuir as incertezas existentes, relacionadas, por exemplo, ao perfil socioeconômico e ao clima, parâmetros que variam de acordo com a região de estudo. Como resultado, este trabalho mostra que em todos os bairros observados a sugestão normativa para o valor de $\mathrm{Cp}$ ficou abaixo dos valores obtidos pela aplicação das equações empíricas e pela avaliação dos dados de consumo hídrico, em todos os anos aos quais se referiram os estudos. Desta maneira, a referência normativa não foi suficientemente adequada para descrever o consumo hídrico em nenhum dos anos avaliados. Ademais, a avaliação por meio dos dados de consumo hídrico indicou um coeficiente de pico equivalente a $240 \%$ da sugestão normativa (2,4 vezes maior) ao passo em que as equações empíricas sugerem a adoção de um valor correspondente a $200 \%$ do valor indicado pela norma (duas vezes maior). Constatou-se ainda que o cômputo de $\mathrm{Cp}$ por meio de equações empíricas resultou em 
valores 1,55 vezes maiores do que os dados de consumo hídrico indicaram. Como o cálculo da vazão de projeto depende diretamente do coeficiente de pico de consumo, e o uso de valores menores leva evidentemente a vazões de projeto menores. Deste modo, menores diâmetros dimensionados das redes de abastecimento serão determinados e, por consequência direta, maiores perdas de carga serão verificadas nos horários de maior vazão. Esta situação pode resultar em falta de água nos dias e horários de pico de consumo, de forma a não atender a população de forma contínua, que é uma premissa do sistema de abastecimento público. Futuras pesquisas podem se concentrar em ampliar o número de regiões avaliadas na comparação entre diferentes fontes de obtenção de coeficientes de pico de consumo hídrico, podendo-se também explorar a avaliação dos dados de consumo hídrico para determinação do valor de $\mathrm{Cp}$ e posterior correlação com fatores locais como população residente, área de abastecimento, clima típico, entre outros fatores, agregando valor aos resultados já existentes na literatura específica da área, e ampliando também o conhecimento relacionado ao dimensionamento de redes de distribuição de água.

Palavras-chave: Coeficiente de pico; Equação empírica; Consumo hídrico. 


\section{Introduction}

Water in sufficient quantity and quality is essential for all aspects of life and sustainable development (industrial or agricultural), besides promoting health, safety in food production and poverty reduction (United Nations, 2018). The survival of the human species, the preservation of the environment, the biodiversity and the relation between living beings and natural environments are fundamentally dependent on the availability of water (Bacci and Pataca, 2008). Regarding human consumption, this resource is substantial for survival, being related to food preparation, hygiene, sanitation, energy generation, industrial activities and several other elements (Santos, 2018).

In this context, water supply systems are designed, and they are characterized by infrastructure for water collection, treatment, storage and the distribution network of drinking water (Heller and Padua, 2006). This paper focuses on the distribution network, which, according to Righetto (2002), must guarantee adequate water supply in each point of the network, with the appropriate pressures, under normal and abnormal conditions of demand.

The design of a water distribution system presupposes knowledge about the demand flow $Q_{d}$. For that, it is necessary to know the definitions of consumption flow $Q_{w c}$ and leakage flow $Q_{w l}$. According to Trifunovic (2006), $Q_{w c}$ is the amount of water directly used by consumers, and $Q_{w l}$ is the amount of water physically lost in the system, so that $Q_{d}$ is given by Equation 1.

$$
Q_{d}=Q_{w c}+Q_{w l}
$$

$Q_{w c}$ and $Q_{w l}$ being expessed in $\mathrm{m}^{3} / \mathrm{h}$ or $\mathrm{m}^{3} / \mathrm{s}$.

Besides the average and total consumption, the design of the distribution network must take into account the fluctuations of water demand to calculate $\mathrm{Q}_{w c}$. For that, peak demand factors are used, which are dimensionless coefficients, obtained from the quotient between the demand at a specific instant and the average demand for a given period (Trifunovic, 2006). Two coefficients widely used to calculate the water distribution systems 
are the coefficient of the day of greatest consumption $\mathrm{K}_{1}$ and the coefficient of the hour of greatest consumption $\mathrm{K}_{2}$.

According to Tsutiya (2006), calculating $K_{1}$ is done by observing the month with the greatest water consumption during the period of one year. Subsequently, the day of that month with the greatest consumption is verified, and this is divided by the annual daily average, obtaining the coefficient. Following the same concept, $\mathrm{K}_{2}$ is obtained from the quotient between the maximum hourly consumption on the day of greatest consumption and the hourly average consumption on that day. After calculating $K_{1}$ and $K_{2}$, the consumption flow is determined from Equation 2 (Porto, 2006):

$$
Q_{w c}=\frac{K_{1} \cdot K_{2} \cdot p \cdot q_{m}}{h}
$$

where $\mathrm{p}$ is the population to be supplied, calculated from statistical methods for popultaion forecast; $q_{m}$ is the per capita average consumption, in L/hab/day; and $\mathrm{h}$ is the system operation hours.

The use of peak coefficients without the knowledge of the consumption profile of the region to be supplied can lead to undersizing the distribuition network, because the calculation of the design flow depends directly on the peak consumption coefficient, as presented by Equation 2. Smaller coefficients lead to smaller design flow rates, resulting in smaller diameters of the system and generating greater head losses at peak hour flow, as presented by the Darcy-Weisbach head loss equation (Equation 3).

$\Delta h=K \cdot Q^{2}$

where $\Delta h$ is the head loss $(m), K$ is the constant of head loss, and it represents the relation between the diameter and the length of the pipe $(\mathrm{m})$, the friction factor, the gravity acceleration $\left(\mathrm{m} / \mathrm{s}^{2}\right)$ and $\pi$.

From Equation 3, it can be noted that, for a stretch of pipe of the same material, diameter, and length, the greater the flow, the greater the head loss, in a quadratic relationship. Higher head losses result in lower pressures available in the system, which can cause the failure of the supply system, lack of water, insufficient pressure or even an increase in costs of pressurization. The lack of water supply on days and hours of peak consumption 
characterizes a system that operates on a noncontinuous basis, failing to meet the premise of continuous service of the supply system, besides increasing the risk of water contamination, an inherent fact of systems in case of negative pressures.

According to Porto (2006), the characteristics of the region can influence the peak factor, which may vary according to the area of interest, seasons, climate, and unexpected situations, such as the lockdown imposed in several countries due to the Covid-19 pandemic. Balacco et al. (2020) presented the results of a survey showing the impact of population's habits on change in water demand in five cities in Italy, emphasizing the vulnerability in forecasting the demand, especially in a situation of health crisis, when continuous supply is essential.

The peak coefficients can also be estimated from empirical equations that can be found in the internationl literature (Harmon, 1918; Babbitt, 1928; Metcalf and Eddy, 1935; Johnson, 1942; Gifft, 1945), as it is presented by Balacco et al. (2017). The conventional methods used for decades present empirical deterministc equations based on consumption data from a region, but they are applied in several countries, which have differente climatic and social conditions. More recently, De Marinis and Gargano (2004) proposed the use of the Gumbel distribution to relate the peak coefficient based on the population, getting a more adequate relationship. Zhang and Buchberger (2005) developed a methodology to estimate the peak factor through a probabilistic approach using the Poisson rectangular pulse and the Gumbel distribution, which allows to incorporate some characteristics of the distribution system in addition to the population. Following this proposal, Balacco et al. (2017) applied local parameters to the equation of Zhang and Buchberger (2005) and suggested a relationship between the peak factor and the population. The authors assume parameters consistent with the Italian context, such as number of inhabitants per residence (2.6), peak hourly demand factor (1.8), daily usage factors for a single residence and coefficient of variation of the Poisson rectangular pulse for the internal water consumption of a residence $(0.045$ and 0.55 respectively).

The application of these equations in Brazilian regions can lead to uncertainties in the results. To minimize them, one can resort to averaging the results obtained by applying all 
of these equations to a given territory, excluding possible outliers, easily identifiable from visual elements such as graphs. Although the empirical equations have limitations, as they are developed in regions with different characteristics (climate, population habits, economics and presence of hydrometry), their results demonstrate that studies on consumption coefficients are relevant for the correct design of supply networks.

To summarize, the peak consumption factor of a region can be determinated mainly in three ways: through water consumption data; through the application of empirical equations; and through normative suggestion. Whenever possible, the ideal is to work with historical consumption data of at least one year, to avoid effects of seasonality. In the absence of water consumption data, NBR 12218/2017 (Brazilian Association of Technical Standards, 2017) suggests the use of $K_{1}=1.2$ and $K_{2}=1.5$. This is the only Brazilian standard that reccomends a value for the peak coefficients, when there are no other reference sources. In last decade the use of artificial inteligency to predict water demand has grown (Zubaidi et al., 2020), the models are based on historiacal data. Although it show very good results, its is not widely asseceble, specialy in smaller municipalities.

The adoption of standardized peak coefficients, a practice used in several countries, does not necessarily reflect the population's water consumption habits. Huaquisto Cáceres and Chambilla Flores (2019) carried out a study and presented the daily and hourly variation of water consumption in the urban area of Salcedo-Puno in Peru. The coefficients $K_{1}$ and $K_{2}$ were determined through consumption data registered by water meters of 26 houses provided by the water operator company. According to the authors, the national building regulations in Peru suggests values of $\mathrm{K}_{1}=1.3$ and $1.8<\mathrm{K}_{2}<2.5$, if statistical data are not available to calculate them. The obtained values for $K_{1}$ and $K_{2}$ were, respectively, 1.33 and 3.80, the latter being much higher than the one suggested by the local standard. Although there are several factors that can affect water demand, the authors attribute the high $\mathrm{K}_{2}$ value to the intermittent water supply in this region.

Despite being a strategy widely used by utilities due to its easy application, estimating demand using peak coefficients for the day and hour of greatest consumption has a disadvantage - it standardizes the same peak coefficient for the entire supply system 
without taking into account the variations of each sector. Creaco et al. (2018) presented a comparison between three methods to estimate the demand. The first one is based on the traditional method using peak coefficients. The second one is a probabilistic method based on the flow rates of each consumption point in a standard residence and in the probability of being activated simultaneously. Finally, in the third method, demand is estimated through modeling for each consumption point randomly selected and based on a pre-fixed probabilistic distribution. The second and third methods use a time scale that estimates the demand every second, while the first one uses an hour scale. The authors conclude that the traditional method underestimates demand when compared to the other two methods analyzed, especially for small areas. However, this difference narrows when considering a large region. Water consumption reflects characteristics of a population's habits and cannot necessarily be estimated uniformly for the entire water supply system.

This paper presents the results of the peak consumption coefficients obtained from the application of seven empirical equations, available in the literature, in the regions supplied by the Irerê Reservoir (Jardim America II, in Várzea Paulista / SP, interior of the State of São Paulo ) and the Parque Jambeiro and Parque Oziel neighborhoods (both located in Campinas / SP, the third most populous city in the State of São Paulo, with an estimated $1,204,703$ inhabitants in 2019). A comparative analysis was also developed with the values inferred by Chang (2017) and Santos (2018) for these same regions, and with the values recommended by NBR 12218/2017 (Brazilian Association of Technical Standards, 2017). Finally, a survey of hypotheses was made regarding the influence of the divergences found between the calculated and measured values for the recommended ones in the water distribution networks. This survey can be a basis for future research.

In Brazil, estimating the peak coefficients for the design of water supply systems is still little explored. As the incorrect determination can result in discontinuities in water supply, a research gap in the topic is identified. In this way, this paper contributes by adding value to the results existing in the specific literature of the area, verifying the consistency of the results obtained with the normative standards. 


\section{Material and Methods}

To develop a comparative analysis of the consumption coefficients for three locations in the interior of São Paulo State, the results obtained from seven empirical equations selected from the literature are presented in the first part of the Results and Discussion section. These equations were applied to three locations: Jardim America II, in Várzea Paulista / SP; and Parque Jambeiro and Parque Oziel, both located in Campinas / SP. The input data for the equations is the total population supplied. Next, the results of coefficients obtained from the survey of consumption profiles are presented, based on historical flow data, provided by the concessionaires, and taken from the works of Chang (2017) and Santos (2018) for the same three locations. In the last part, a comparison with the values recommended by the technical standard is presented, evaluating the differences found between the calculated values and the measured values.

Santos (2018) evaluated the water consumption data for the area supplied by the Irerê reservoir, located in the municipality of Várzea Paulista / SP, in the 2015, 2016 and 2017 triennium, concluding that the values suggested by NBR 12218/2017 for $\mathrm{K}_{1}$ and $\mathrm{K}_{2}$ were less than the demand for the location actually demonstrated, as presented in Figure 1.

Figure 1 - Comparison between values calculated for the peak coefficients $K_{1}$ and $K_{2}$ and those suggested by the NBR 12218/2017 (Santos, 2018)

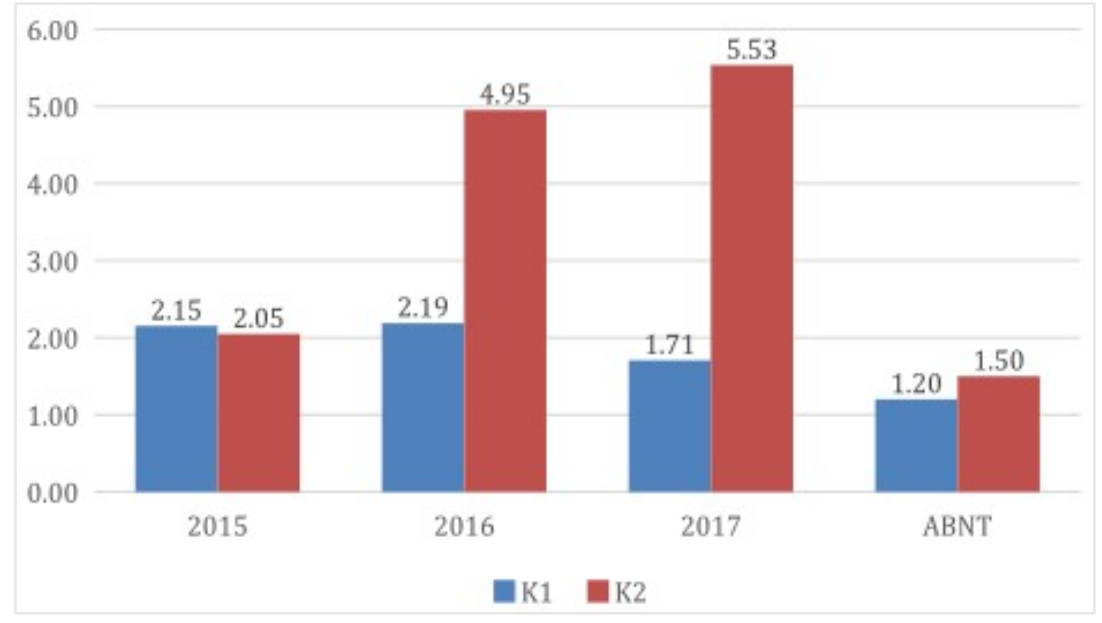

Chang (2017) also carried out an analysis to infer the peak coefficients of a region from the consumption. He evaluated the data of the reservoir's output volume in two sectors 
of the city of Campinas / SP (Parque Jambeiro and Parque Oziel), in the period between 2014 and 2017. The relative differences between the values found for the peak coefficients and those recommended by NBR 12218/2017 (Brazilian Association of Technical Standards, 2017) were lower than those referring to the Irerê reservoir (shown in Figure 1). However, the peak coefficients obtained in the two regions of Campinas / SP also indicated that the use of $K_{1}=1.2$ and $K_{2}=1.5$ may incur in undersizing of the system for some years, as shown in Table 1.

Table 1 - Values of peak water consumption coefficients in Parque Jambeiro and Parque Oziel between 2014 and 2017 (Chang, 2017)

\begin{tabular}{ccccc}
\hline \multirow{2}{*}{ Year } & \multicolumn{2}{c}{ Parque Jambeiro } & \multicolumn{2}{c}{ Parque Oziel } \\
\cline { 2 - 5 } & $\boldsymbol{K}_{\mathbf{1}}$ & $\boldsymbol{K}_{\mathbf{2}}$ & $\boldsymbol{K}_{\mathbf{1}}$ & $\boldsymbol{K}_{\mathbf{2}}$ \\
\hline 2014 & 1.19 & 1.53 & 1.32 & 1.74 \\
\hline 2015 & 1.30 & 1.40 & 1.46 & 1.73 \\
\hline 2016 & 1.24 & 1.35 & 1.68 & 2.06 \\
\hline 2017 & 1.29 & 1.74 & 1.31 & 1.53 \\
\hline Average & 1.26 & 1.50 & 1.44 & 1.77 \\
\hline
\end{tabular}

The research of Chang (2017) and Santos (2018) is based on water consumption data provided by the private company responsible for the treatment and distribution of water in the respective locations, and the values obtained are presented in Figure 1 and Table 1. These results were used in the present research as the representative values of the evaluation of the peak coefficient through the analysis of consumption data.

To assess the application of empirical equations, correlations developed in different regions and already available in the literature were used. Population of the study regions was estimated based on population and demographic density data provided by government agencies. As the empirical equations were developed in regions that little resemble the demographic and socioeconomic conditions of those evaluated by this article, the average of the results obtained through these equations was used, to reduce the uncertainties. The empirical equations used in this study follow those approached by Balacco et al. (2017) and correlate the peak coefficient $\mathrm{Cp}$, defined by the product of the hourly and daily peak coefficients with the population of the territory in question. 
With $\mathrm{N}$ being the population of the supplied region, in thousands of inhabitants, Harmon (1918) proposed a relationship between Cp and the population of a region, shown by Equation 3

$$
\mathrm{Cp}=\frac{18+\sqrt{N}}{4+\sqrt{N}}
$$

Denominating $\mathrm{P}$ as the population of the supplied region in number of inhabitants, Babbitt (1928) also explored a direct correlation between the population and the peak coefficient, shown by Equation 4:

$$
\mathrm{Cp}=20 * P^{-0.2}
$$

Metcalf and Eddy (1935) proposed that for populations larger than five thousand inhabitants, the Cp decreases logarithmically, and for smaller populations the Cp is constant, as shown in Equation 5:

$$
\mathrm{Cp}= \begin{cases}4, & N \leq 5 \\ \frac{4.8}{N^{0.113}} & N>5\end{cases}
$$

Johnson (1942) found the expression shown in Equation 6 for the relationship between the population and Cp:

$$
\mathrm{Cp}=\frac{5.2}{N^{0.15}}
$$

Gifft (1945) made a review of the equation, from data obtained by Metcalf and Eddy (1935) and Johnson (1942), concluding that Equation 7 better describes the relationship between the population and $\mathrm{Cp}$.

$$
\mathrm{Cp}=\frac{5}{N^{0.167}}
$$

From the study realized by Babbitt (1928), De Marinis and Gargano (2004) used the Gumbel distribution to describe the relationship between the peak coefficient and the population, shown by Equation 8:

$$
\mathrm{Cp}=11^{*} P^{-0.2}
$$

Equations developed using a deterministic approach can provide a considerable error, due to the randomness observed in the water demand (Balacco et al., 2017). So, Balacco et al (2017) proposed Equation 9, based on results of Zhang and Burchberger (2005), who developed a methodology based on the reliability to estimate instantaneous peaks of 
residential water consumption. Although not considered an empirical approach, it does assume some parameters, as previously mentioned.

$$
\mathrm{Cp}=1.8+\frac{1.8}{\sqrt{N}}
$$

The application of these equations presupposes knowledge about the region's population. About Parque Jambeiro, the municipality of Campinas provides, through its website, a population equivalent to 9128 inhabitants. In the case of Parque Oziel and Jardim America II, the population was established by means of the product of the area and the estimated demographic density for that region, corresponding to 1660 and 1890 inhabitants, respectively.

The normative reference used as a basis for the developed comparative analysis is the NBR 12218/2017 (Brazilian Association of Technical Standards, 2017), which is the one of the few Brazilian standards to recommend a value for peak water consumption coefficients in the absence of other sources (such as consumption data).

\section{Results and Discussion}

The results obtained show that for all the neighborhoods considered, the values suggested by the normative standard was overcome by both, the application of empirical equations and the evaluation of water consumption data, for all the years previously developed and used as a basis for this paper. Therefore, the normative reference was not adequate, or sufficient, to describe water consumption for any of the years analyzed.

Equations 3 to 9 were used to determine the peak coefficient of the three regions evaluated. For this, the populations of 9128,1660 and 1890 inhabitants were considered for Parque Jambeiro (Campinas / SP), Parque Oziel (Campinas / SP) and Jardim America II (Várzea Paulista / SP), respectively. Table 2 presents the results obtained, while Figure 3 shows a graph that allows a better visual evaluation of the peak water consumption coefficient values presented in Table 2. 
Table 2 - Values of peak water consumption coefficients for each region based on empirical equations by their respective authors

\begin{tabular}{|c|c|c|c|c|c|c|c|}
\hline \multirow[b]{2}{*}{ Region } & \multicolumn{7}{|c|}{ Peak Coefficient (Cp) by empirical equations } \\
\hline & $\begin{array}{c}\text { Harmon } \\
(1918)\end{array}$ & $\begin{array}{c}\text { Babbitt } \\
(1928)\end{array}$ & $\begin{array}{c}\text { Metcalf } \\
\text { and } \\
\text { Eddy } \\
\text { (1935) }\end{array}$ & $\begin{array}{c}\text { Johnson } \\
\text { (1942) }\end{array}$ & $\begin{array}{c}\text { Gifft } \\
\text { (1945) }\end{array}$ & $\begin{array}{c}\text { De Marinis } \\
\text { and } \\
\text { Gargano } \\
(2004)\end{array}$ & $\begin{array}{c}\text { Balacco } \\
\text { et al. } \\
\text { (2017) }\end{array}$ \\
\hline Pq. Jambeiro & 2.99 & 3.23 & 3.74 & 3.73 & 3.46 & 1.78 & 2.40 \\
\hline Pq. Oziel & 3.65 & 4.54 & 4.00 & 4.82 & 4.59 & 2.50 & 3.20 \\
\hline $\begin{array}{l}\text { Jd. America } \\
\text { II }\end{array}$ & 3.60 & 4.42 & 4.00 & 4.73 & 4.50 & 2.43 & 3.11 \\
\hline
\end{tabular}

Figure 3 - Comparative bar graph relative to the values calculated for the peak coefficient Cp based on empirical equations (Own authorship)

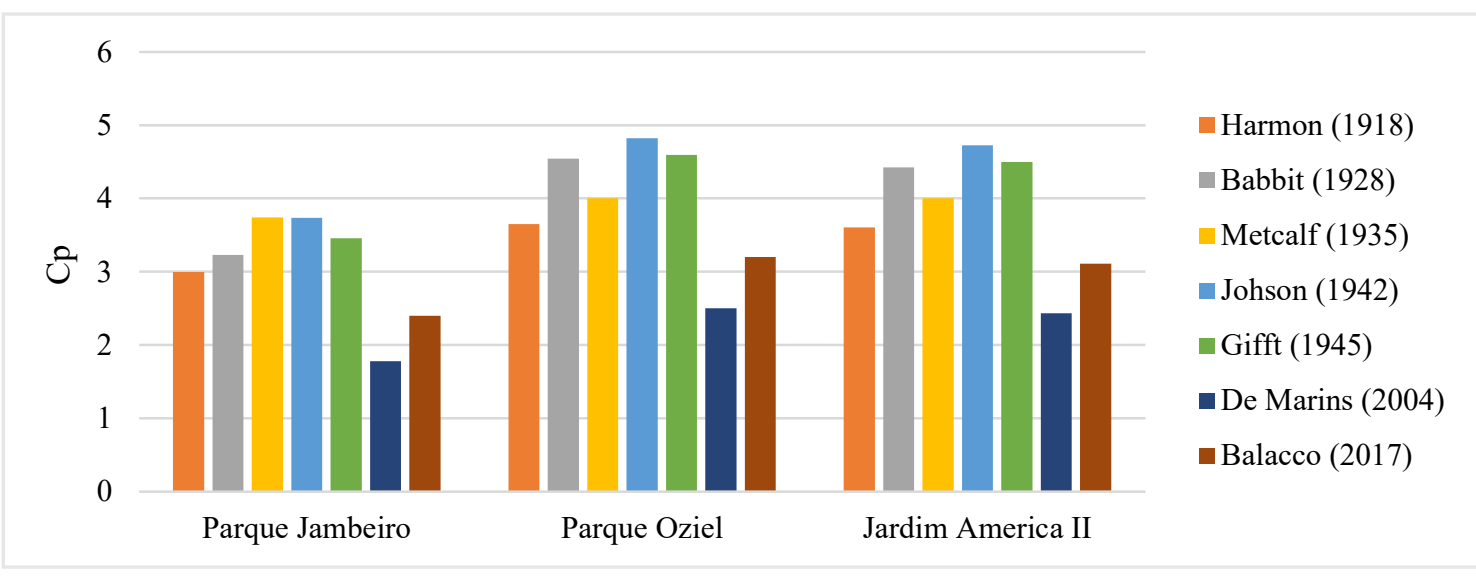

Using the average of the peak consumption coefficient obtained from the application of the empirical equations, and by the assessments of Chang (2017) and Santos (2018), a bar graph was constructed (Figure 4), which shows the similarities and differences experienced by these two sources of results. These values were also compared with the peak coefficients suggested by the standard.

The values of the empirical equations presented for the three regions regarding the equations proposed by De Marinis and Gargano (2004) and Balacco et al. (2017) resulted in $\mathrm{Cp}$ values between 1.78 and 3.6. For the regions of Parque Jambeiro and Parque Oziel, the values raised by historical data are between 1.67 and 3.46 (considering the data for the years 2014 to 2017), which shows a good representation of the peak coefficient values by the 
equations, that is, the use of a $\mathrm{Cp}$ forecast equation for these sectors would lead to a network better sized than the adoption of the normative suggested values, avoiding undersizing the networks.

For a better visualization of the results provided by the empirical equations, the mean of all equations was used. Each one of these equations has its source of data in different regions of the world, and none of them has been developed by observing data from Brazilian regions. Therefore, using the mean of the values is a more assertive strategy than choosing one of them. In addition, the peak coefficient suggested by the standard, equal to 1.8 , is given by the product of the daily peak coefficient $\left(K_{1}\right)$, corresponding to 1.2 , and the hourly peak coefficient $\left(K_{2}\right)$, corresponding to 1.5 .

The results of Chang (2017) and Santos (2018) are related to each year in which water consumption data was assessed. For this reason, the product was taken for the average of the values presented for $K_{1}$ and $K_{2}$. In the case of Parque Jambeiro and Parque Oziel, the average values can be seen in Table 1. In the case of Jardim America II, the values of $K_{1}$ and $\mathrm{K}_{2}$ are shown in Figure 1. Table 3 shows the values corresponding to each source peak water consumption coefficient.

Table 3 - Peak water consumption coefficients for the three study regions obtained from three different sources (empirical equations, normative suggestion and evaluation of water consumption data)

\begin{tabular}{ccccc}
\hline \multirow{2}{*}{ Region } & \multicolumn{4}{c}{ Cp } \\
\cline { 2 - 5 } & $\begin{array}{c}\text { Average value } \\
\text { obtained from } \\
\text { empirical equations }\end{array}$ & $\begin{array}{c}\text { Value } \\
\text { suggested by } \\
\text { NBR }\end{array}$ & $\begin{array}{c}\text { Average value obtained from } \\
\text { the consumption data }\end{array}$ \\
\cline { 2 - 5 } & $\mathbf{1 2 2 1 8 / 2 0 1 7}$ & Chang (2017) & $\begin{array}{c}\text { Santos } \\
(\mathbf{2 0 1 8})\end{array}$ \\
\hline Parque Jambeiro & 3.05 & 1.80 & 1.89 & - \\
\hline Parque Oziel & 3.90 & 1.80 & 2.55 & - \\
\hline Jardim America II & 3.83 & 1.80 & - & 8.42 \\
\hline
\end{tabular}

The evaluation of the data presented in Tables 1, 2 and 3 and in Figure 4 allows us to observe that the values provided by the application of the empirical equations developed by Harmon (1918), Babbitt (1928), Metcalf and Eddy (1935), Johnson (1942), Gifft (1945), De Marinis and Gargano (2004) and Balacco et al. (2017) were higher than the values suggested 
by NBR $12218 / 2017$ for the three evaluated regions. For the territories corresponding to Oziel Park and Jardim America II, the empirical equations suggest a peak coefficient equivalent to approximately $200 \%$ (217\% and $213 \%$, respectively) of that suggested by NBR $12218 / 2017$. For Parque Jambeiro, this percentage is $169 \%$. Therefore, it can be concluded that the values provided by the empirical equations exceeded the value recommended by NBR 12218/2017, on average, by $199 \%$ (which corresponds to the average of the three percentages presented).

Figure 4 - Comparative bar graph related to the values calculated for the peak coefficient $\mathrm{Cp}$ based on assessments of consumption data, application of empirical equations and normative suggestion (Chang, 2017; Santos, 2018; NBR 12218/2017)

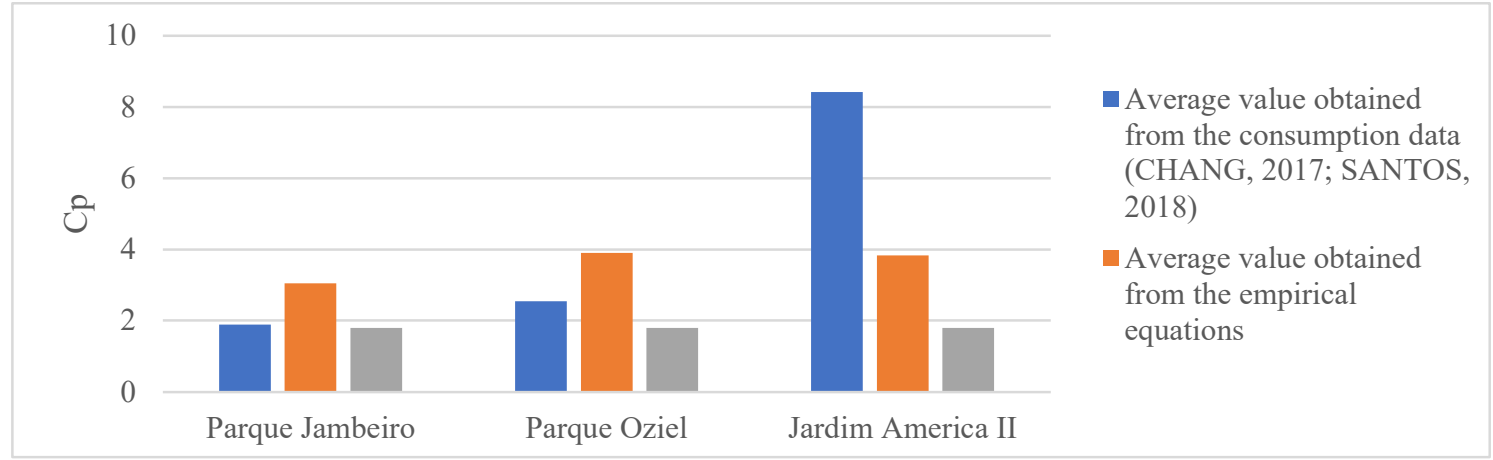

It is also possible to note that in all cases the value corresponding to the normative recommendation is exceeded by the values provided by the analysis of water consumption data made by Chang (2017) and Santos (2018). At Parque Jambeiro, the value obtained by analyzing consumption data is equivalent to $105 \%$ of the normative value. In relation to Parque Oziel, this percentage rises to $142 \%$. For Jardim America II, the observed ratio is $468 \%$, which is the most discrepant value observed in the comparative analyses carried out. Thus, one may conclude that the values obtained through the evaluation of water consumption data exceeded the values recommended by NBR 12218/2017, on average, by $238 \%$.

Figure 5 shows the divergences between the values obtained through the empirical equations and through the water consumption data in relation to the normative value, allowing a better understanding. 
Figure 5 - Relation between the obtained $\mathrm{Cp}$ and those one suggested by NBR 12218/2017 (Own authorship)

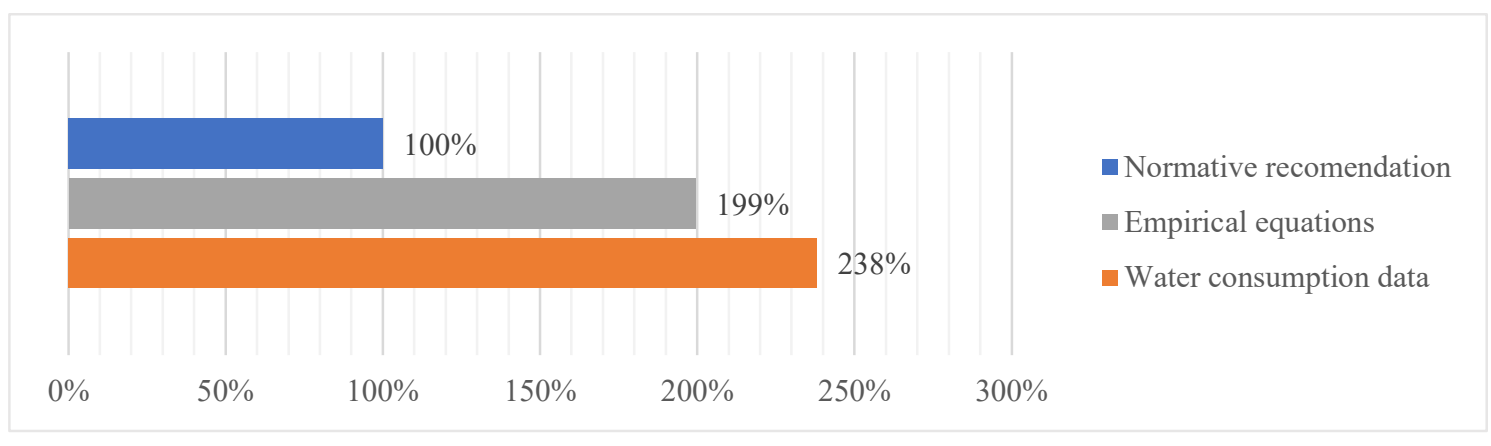

The value of the peak water consumption coefficient provided by the empirical equations exceeded the value obtained from the water consumption data in the regions of Parque Jambeiro and Parque Oziel (by $161 \%$ and 153\%, respectively) and in the area of Jardim America II (220\%). Generally, the peak coefficient obtained from water consumption data was, on average, $119 \%$ higher than those obtained from the application of empirical equations (Figure 6).

Figure 6 - Relation between the $\mathrm{Cp}$ obtained from the water consumption data and those one obtained from the empirical equations (Own authorship)

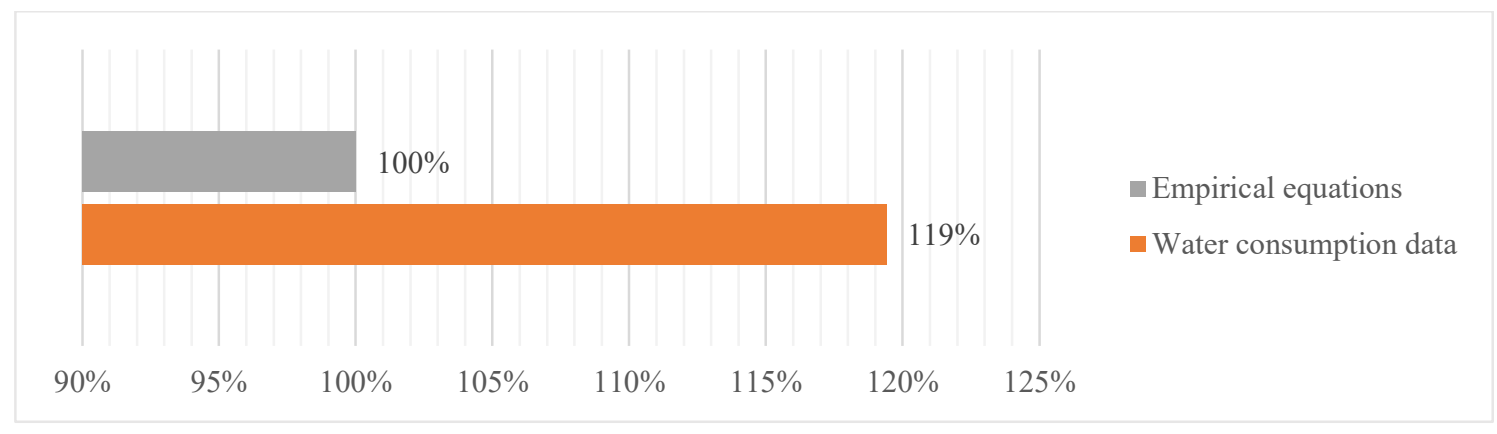

From Figures 5 and 6, it can be concluded that the adoption of a consumption coefficient value, without surveying both the local conditions and consumption profiles, could lead to undersizing the water supply networks, being vulnerable to water shortage. As an example, using Equations 2 and 3 for the design a hypothetical pipeline to supply a sector with the same size of Parque Jambeiro, with about 2000 water connections, considering the 
coefficient of consumption $\mathrm{Cp}=1.8$, the design foreseeing peak flow of $25 \times 10^{-3} \mathrm{~m}^{3} / \mathrm{s}$, would require a theoretical diameter of $0.192 \mathrm{~m}$, and commercial diameter equal to 0.200 $\mathrm{m}$. Considering the same characteristics regarding pipeline extension, material, per capita consumption and inhabitant density per connection but changing only the consumption profile $\mathrm{CP}=2.7$, this would result in a peak flow of $37.5 \times 10^{-3} \mathrm{~m}^{3} / \mathrm{s}$ and a pipeline diameter equal to $0.250 \mathrm{~m}$ pipeline. The same flow in the $0.200 \mathrm{~m}$ pipeline would result in a head loss around $100 \%$ above that predicted.

Another important aspect to note is the variability of peak consumption coefficients related to the region in which they are assessed. In the case of the normative recommendation, the suggested value is constant and does not depend on the region in which the analysis is being carried out. Regarding the empirical equations, the value depends on the population presented by the territory, and therefore it varies according to the region: in the three neighborhoods evaluated, the largest variation observed was between Parque Jambeiro $(C p=3.05)$ and Parque Oziel $(C p=3.90)$, resulting in an absolute difference of 0.85 .

Greater variability is found when observing the average value obtained from the consumption data: for Parque Jambeiro, $\mathrm{Cp}=1.89$, while for Jardim America II, $\mathrm{Cp}=8.42$, resulting in an absolute difference of 6.53 . This difference occurs due to several factors, for instance, socioeconomic profiles. According to Chang (2017), Parque Jambeiro is a middleclass residential area, and Parque Oziel is a lower-class residential area, while Jardim America II, according to Santos (2018), consists of lower-middle and lower-class residential areas. Other factors such as possible abrupt variations in climatic conditions and interruptions in supply and singularities such as the water crisis in 2014 may have contributed to the disparity in consumption profiles.

\section{Conclusion}

This paper presented a comparative analysis of the values of peak water consumption coefficients $(C p)$ obtained from three different sources. In the first one, $C p$ values were calculated by Chang (2017) and Santos (2018) from water consumption data. In the second 
one, $\mathrm{Cp}$ values were calculated from empirical equations. Finally, the third considered the recommendations of NBR 12218/2017. These sources were applied in three different areas: Parque Jambeiro (Campinas/SP), Parque Oziel (Campinas/SP) and Jardim America II (Várzea Paulista/SP).

The values of $\mathrm{Cp}$ obtained from the empirical equations resulted, on average, about two times greater than those obtained from the value suggested by NBR 12218/2017. Regarding the use of water consumption data, the obtained $\mathrm{Cp}$ was, on average, approximately 2.4 times greater than that recommended by the normative standard.

It is also noticeable that in all the neighborhoods assessed, the normative suggestion was overcome by both applications of empirical equations and by the evaluation of water consumption data, in all the years to which the studies of Chang (2017) and Santos (2018) were applied. Thus, there is no year in which the normative reference was adequate or sufficient to describe water consumption. These results indicate that the distribution networks of several water supply systems may be undersized, in view of the wide use of the value recommended by NBR $12218 / 2017$ in the design of the networks, being one of the few references that refer to a value to be adopted for $\mathrm{Cp}$.

The application of empirical equations resulted in a Cp greater than those obtained from water consumption data for two of the three regions evaluated. The exception occurred in Parque Jambeiro, in which the highest Cp value obtained was observed among all those evaluated (corresponding to $\mathrm{Cp}=8.42$ ). Although this value cannot be considered as an outlier, as it has a physical meaning and is not large enough to incur absurdity, it differs from the other observations. Some hypotheses that explain this are the atypical water consumption, the measurement error in the reservoir volume or in $\mathrm{Cp}$ accounting or the start of irregular consumption trend in certain periods of the year. Future research on the assessment of the peak coefficients of this region for other years is necessary to validate any of these hypotheses.

Excluding what occurred in Parque Jambeiro, it may be said that there is a tendency that the use of empirical equations results in values of peak coefficients greater than that indicated by water consumption data, with a safety factor of approximately 1.55 (that is, the 
average value obtained from the empirical equations is $55 \%$ greater than the average value obtained from the evaluation of water consumption data). It can also be concluded that since the demand flow $Q_{d}$ depends on the peak coefficient, the undersizing can result in an eventual lack of water on the days when peak consumption is verified (especially if the supply capacity of the water source is not high). Finally, it can be concluded that the best indication for new projects is to collect regional data to define the consumption profile. In the absence of these data, the application of formulas that consider the local population can lead to better results than simply the adoption of a reference value that has no relation to the location of the project.

For future research, the authors suggest expanding the total number of regions assessed in the comparison between different ways to calculate the peak water consumption coefficients, using the data presented here and expanding the knowledge in the specific literature. In addition, the absence of empirical equations developed in Brazilian regions is verified, which makes it difficult to determine the peak coefficients for the design of water distribution networks and induces the use of the suggested normative value, which may be underestimated.

\section{Acknowledgments}

The authors would like to thank CAPES (Coordenação de Aperfeiçoamento de Pessoal de Nível Superior) and CNPq (Conselho Nacional de Desenvolvimento Científico e Tecnológico) for the scholarship. We also thank the SABESP (Companhia de Saneamento Básico do Estado de São Paulo) and SANASA (Sociedade de Abastecimento de Água e Saneamento), for making data available, FAPESP (Fundação de Amparo à Pesquisa do Estado de São Paulo - process 2017/09921-2) and BRWC (Brazilian Water Research Center - FAPESP process 2019/11353-8) for the financial support, essential for this research, and UNICAMP (Universidade Estadual de Campinas) for providing all the necessary means to carry out this study.

\section{References}


ASSOCIAÇÃO BRASILEIRA DE NORMAS TÉCNICAS. NBR 12218: Projeto de rede de distribuição de água para abastecimento público - Procedimento. Rio de Janeiro, 2017.

BABBITT, H. E. Sewerage and Sewage Treatment. 3. ed. New York: Wiley, 1928.

BACCI, D.; PATACA, E. Educação para a água. Estudos Avançados, v. 22, n. 63, p. 211-226, 2008.

BALACCO, G. et al. Evaluation of peak water demand factors in Puglia. Water, v. 9, n. 2, art. 96, 2017.

BALACCO, G. et al. Influence of COVID-19 Spread on Water Drinking Demand: The Case of Puglia Region ( Southern Italy ). n. February, 2020

CHANG, P. S. Revisão dos coeficientes de consumo e após a crise hídrica em dois setores da cidade de Campinas: Parque Jambeiro e Parque Oziel. [s.I.] Universidade Estadual de Campinas - Unicamp, 2017.

CREACO, E. et al. Peak demand assessment and hydraulic analysis in WDN design. Journal of Water Resources Planning and Management, v. 144, n. 6, 2018.

DE MARINIS, G.; GARGANO, R. [The Flow demand for small residentian villages]. Proceedings. In: $23^{\circ}$ Convegno di Idraulica e Costruzioni Idrauliche. Anais...Treto, Italia: 2004 Italian

GIFFT, H. M. Estimating variations in domestic sewage flows. Water Works Sewage, v. 92, p. 175-177, 1945.

HARMON, W. Forecasting sewage at Toledo under dry weather conditions. Engineering News Record, v. 80, p. 1233, 1918.

HELLER, L.; PADUA, V. L. Abastecimento de água para consumo humano. 1. ed. Belo Horizonte: [s.n.], 2006.

HUAQUISTO CÁCERES, S.; CHAMBILLA FLORES, I. G. Análisis Del Consumo De Agua Potable En El Centro Poblado De Salcedo, Puno. Investigacion \& Desarrollo, v. 19, n. 1, p. 133-144, 2019.

JOHNSON, C. F. Relation between average and extreme sewage flow rates. Engineering News Reccord, v. 129, p. 500-501, 1942.

METCALF, L.; EDDY, H. P. American Sewerage Practice, Volume III: Design of Sewers. Vol. I, 3 ed. [s.l.] McGraw Hill, 1935.

PORTO, R. DE M. Hidráulica Básica. Quarta Edi ed. [s.I.] Publicações EESC-USP, 2006.

RIGHETTO, A. M. Operação ótima de sistema urbano de distribuição de água. Seminário: 
Planejamento, Projeto e Operação de Redes de Abastecimento de Águ. Anais...2002

SANTOS, A. L. R. 2018. Avaliação dos coeficientes de consumo de água K1 e K2: influência das características do bairro Jardim América II nos coeficientes de consumo K1 e K2. [s.l.] Universidade Estadual de Campinas - Unicamp, 2018.

TRIFUNOVIC, N. Introduction to urban water distributionUnesco-IHE Lecture Note SeriesCRC Press, , 2006.

TSUTIYA, M. T. Abastecimento de água. Quarta ed. [s.I.] Departamento de Engenharia Hidráulica e Sanitária da Escola Politécnica da Universidade de São Paulo, 2006.

UNITED NATIONS. Sustainable Development Goal 6 Synthesis Report on Water and Sanitation 2018. New York: [s.n.].

ZHANG, X.; BUCHBERGER, S. A theoretical explanation for peaking factors. ASCE EWRI Conferences. Anais...2005

ZUBAIDI, S. L. et al. A novel methodology for prediction urban water demand by wavelet denoising and adaptive neuro-fuzzy inference system approach. Water (Switzerland), v. 12, n. 6, 2020. 